\title{
EVALUATION OF WOODEN MATERIALS DETERIORATED BY MARINE-WOOD BORING ORGANISMS IN THE BLACK SEA
}

\author{
H. Sivrikaya ${ }^{1}$, H. Hafizoğlu ${ }^{1}$, S.M. Cragg ${ }^{2}$, A. Carrillo ${ }^{3}$, \\ H. Militz ${ }^{4}$ C. Mai ${ }^{4}$, L.M.S. Borges ${ }^{5}$
}

\begin{abstract}
Marine borers can destroy wooden structures exposed to the marine environment and cause great monetary loss. In the region of Amasra of the Black Sea in Turkey, ships continue to be built from wood, mainly Castanea sativa (sweet chestnut) and Quercus petraea (sessile oak) and therefore are subject to destruction by marine borers. Copper-chromium-arsenic (CCA), used to be one of the most common wood preservatives used in Turkey. However, in this area its efficacy against marine borers is unknown. The resistance of untreated and CCA-treated samples of chestnut, oak and Scots pine (Pinus sylvestris) was examined and after twelve months evaluated in two ways, EN 275, and a non-destructive measurement for dynamic modulus of elasticity (MOE). Untreated samples, particularly Scots pine were severely attacked by Teredo navalis. Treated samples of oak and chestnut were moderately attacked while treated samples of Scots pine sapwood and heartwood were sound. Severity of wood boring attack determined using MOE showed a very good correlation with that determined by visual assessment in untreated wood, and a good correlation for treated wood. Dynamic MOE allows rapid on-site evaluation rather than measurements within a laboratory and also without causing damage to the structures being evaluated.
\end{abstract}

Keywords: non-destructive testing, Dynamic Modulus of Elasticity (MOE), wooden material, CCA, marine borers, Teredo navalis.

\section{INTRODUCTION}

Timber has been used as a construction material in the marine environment for centuries. In Turkey some wood species such as oak (Quercus petraea) and chestnut (Castanea sativa) have been widely used for maritime construction. Oak is the most widespread species in Turkey, covering $30 \%$ of the total forest area. Chestnut although less common in Turkey, involving $1.4 \%$ of the total forest area of Turkey (OGM 2007) is widely used in the Black Sea region for the major parts of the yacht and boat building as well as to the constructions such as pier and jetty. Both oak and chestnut are rich in extractives, which makes them resistant to some wood-degrading organisms (Nicholas 1973).

Timber exposed to the marine environment is susceptible to wood decaying micro-organisms such as fungi and bacteria (Eaton and Hale 1993), however, the primary agents of wood degradation in the sea are wood boring organisms, which include bivalves of the families Teredinidae and Pholadidae (Turner 1966), and crustaceans of the families Limnoriidae, Sphaeromatidae (Menzies 1957) and Cheluridae (Cragg and Daniel 1992). Untreated oak and chestnut have been shown to be

\footnotetext{
${ }^{1}$ Bartin University, Faculty of Forestry, 74100, Bartin, Turkey

${ }^{2}$ University of Portsmouth, Institute of Marine Sciences, Ferry Road, Portsmouth PO4 9LY, UK

${ }^{3}$ Facultad de Ciencias Forestales, Universidad Autónoma de Nuevo León, Carr. Nacional Km 145, Ap. Postal 41 Linares, N.L. México

${ }^{4}$ University of Göttingen, Institute for Wood Biology and Wood Technology Büsgenweg 4 DE 37077 Göttingen, Germany

${ }^{5}$ University of Minho, Department of Biology, Centre of Molecular and Environmental Biology, Campus de Gualtar, $4710-057$ Braga, Portugal

Received: 11.07. 2011 Accepted: 29.01. 2012.

Corresponding author: hsivrikaya@bartin.edu.tr
} 
significantly more resistant to Limnoria quadripunctata than the non-durable species Scots pine in the laboratory assay which was determined based on feeding rates measured by faecal pellet production over a two week period. Pellet production was significantly lower on oak and chestnut than on either the heartwood or sapwood of Scots pine (Sivrikaya et al. 2009). However, their resistance to the wood boring organisms occurring in Amasra has not been evaluated. Therefore one of the aims of this study was to evaluate the resistance of untreated panels of these two species to marine wood borers occurring in Amasra Bay, with Pinus sylvestris included for comparison, and the others were to determine the efficacy of the CCA in the region and to assess the samples non-destructively .

In marine environments with high marine borer activity even the most resistant wood species show some susceptibility to attack by these organisms (Borges et al. 2008, Williams et al. 2004). Thus protection from teredinids and limnoriids is necessary in virtually all coastal areas. Therefore, methods of conferring additional protection to wood have been sought. Treatment with preservatives such as copper-chromium-arsenic (CCA) enhances the durability of various timber species to different degrees (Rao et al. 2001). In Northern waters for example, CCA confers good protection against teredinids and limnoriids (Fougerousse and Lucas 1976). Softwood and hardwood samples treated with creosote and CCB (copper, chrome, boron) were found to be sound on the Turkish coastlines after 14 months exposure (Bobat 1995). The combination of chlorothalonil and chlorpyrifos provided superior effectiveness against various marine borer species (Woods et al. 1995). The wood preservatives such as creosote and CCA with vacuum-pressure treatments provide effective protection against teredinids that has been demonstrated by long-term field trials (Cragg et al. 1999, Eaton 1989, Cookson and Barnacle 1987). However, there are growing environmental concerns about the use of CCA, resulting in its restriction or banning in many countries. The use of CCA wood preservatives was banned by US-EPA in the residential applications such as decks, fences and playground components effective as of December 31,2003, and effectively restricted the use of CCA to the treatment of wood used primarily in industrial and agricultural applications. Therefore alternatives have been sought to protect wood in the marine environment, such as chemically modified wood (Borges 2007; Westin and Rapp 2005). Nevertheless, there is almost no study on the performance of CCA on the coastline of the Black Sea region. Thus it was important to test its efficacy against marine wood borers when used as a treatment for Q. petraea and C. sativa.

The severity of attack by wood boring organisms in test panels is generally evaluated using two methods. X - rays that readily detect the calcareous linings of tunnels can be used to determine the extent of attack by teredinids (EN 275, 1992). To rate the surface attack by limnoriids, visual assessment is used. Visual assessment can also be used to evaluate teredinid attack by splitting open the wood to reveal the percentage of attack (Borges 2007). These methods although relatively simple to perform are not applicable when evaluating larger wooden structures such as jetties or navigational dolphins. Therefore an alternative non-destructive acoustic method, which could be used in the laboratory experiment with the wood samples exposed to marine trial, would be useful if it was used in the field. The non-destructive ultrasonic system can be used successfully to inspect timber piled structures which are in service underwater, and provide owners and managers with accurate data that will save money (Morin et al. 2007). However, there is no report in relation to the usability of an acoustic technique below the water line.

The dynamic modulus of elasticity (MOE) provides a simple, reliable and non-destructive tool for the assessment of fungal wood decay. This suggests that it might also be useful to assess severity of attack caused by wood boring organisms in wooden structures exposed to the marine environment. Indeed, determination of fungal decay using MOE proved to be more sensitive than the determination of mass loss, because strength loss due to hydrolysis of the cell wall polysaccharides occurs much earlier than the mineralisation of cell wall constituents (Machek et al. 2001, 2004). Dynamic methods are non-destructive and based on resonant vibration excitation or ultrasonic pulse excitation (Hearmon 1966, Goerlacher 1984), while in static tests the specimens are bent until breakage. High corre- 
lation between static and dynamic measurements was found not only for sound wood (Goerlacher 1984) but also for wood decayed to different extents by soft rot fungi (Machek et al. 1998). In this study we evaluate the potential of dynamic MOE to assess the severity of attack caused by marine wood boring organisms in wooden structures exposed in the sea. To this end we compared the severity of wood boring attack by wood boring organisms in test panels using the standard visual assessment according to EN 275 (1992) and that using dynamic MOE.

\section{MATERIALS AND METHODS}

\section{Wood material}

Test panels were made of three species of wood, Scots pine (Pinus sylvestris L.) sapwood and heartwood, sessile oak (Quercus petraea Liebl.) heartwood and sweet chestnut (Castanea sativa Mill.) heartwood (Table 1). These wood species were obtained from the Bartın province, in the West Black Sea region, Turkey. Ten samples each were prepared from oak and chestnut; five were treated and five remained untreated. In the case of Scots pine, twenty samples were prepared, ten from sapwood and ten from heartwood. Five samples of each were treated and five remained untreated. In addition, three samples of each species were stored under air-dry conditions to be unexposed to the non-destructive testing. All test panels were free from defects such as knots and decay. They were prepared by sawing tangentially to the dimensions of $25 \times 75$ x $200 \mathrm{~mm}$ according to EN 275 (1992) which specifies five panels for marine trial. The panels were conditioned in a climate chamber $(65 \% \mathrm{RH}$ and $20^{\circ} \mathrm{C}$ ) to constant weight before treatment.

\section{Preservation of wood}

The treatment of test panels was carried out in a pilot plant using the full-cell process. The samples were treated with $4 \%(\mathrm{~m} / \mathrm{v})$ Tanalith-C (a CCA salt). The full-cell process was applied with vacuum treatment of $79 \mathrm{kPa}$ for 30 min followed by a pressure treatment of $1500 \mathrm{kPa}$ for $60 \mathrm{~min}$. After the treatment, the excessive solution was removed from the samples, which then were weighed to determine the CCA retention values and \% WPG (weight percent gain). The samples were reconditioned for about four weeks before deployed in the test site.

\section{Panels set-up}

Each test panel was fastened with polypropylene rope in a ladder-like fashion. A gap of $5 \mathrm{~cm}$ was left between each sample and a $5 \mathrm{~kg}$ weight was attached in order to immerse the samples. The panels were suspended vertically $6 \mathrm{~m}$ below low tide, with the larger dimension of the panels orientated horizontally. The samples were left in the sea for 12 months.

\section{Characteristics of test site}

The harbour where the test panels were placed is located in Amasra Bay $\left(41^{\circ} 45^{`} \mathrm{~N}, 32^{\circ} 23^{`} \mathrm{E}\right)$ in the west of the Black Sea. During the test period, sea-surface temperature in the area was monitored monthly.

Maximum sea-surface temperature was observed in August $\left(24.9^{\circ} \mathrm{C}\right)$ while minimum temperature was observed in January $\left(6.3^{\circ} \mathrm{C}\right)$. The average annual sea-surface temperature at the site was $15.4{ }^{\circ} \mathrm{C}$. The average salinity of the sea water is 18 PSU.

\section{Laboratory assessment of test panels}

After a 12-month exposure period, the test samples were retrieved and analysed to determine the severity of wood boring attack. Initially, two out of five test panels of each wood species (untreated and treated) were analysed using a destructive method. The panels were split open to reveal the extent of interior damage and to extract the wood boring organisms. The severity of attack was visually 
assessed, and each panel was rated according to the categories defined in EN 275 (1992). In some cases whole animals were removed from the panels but in others only pallets and shells were found. The teredinids were preserved in $70 \%$ ethanol and identified using the keys in Turner (1971) and descriptions in Turner (1966).

\section{Dynamic MOE test}

Three out of the five test panels were analysed initially using dynamic MOE after the samples conditioned in the climate chamber. The test equipment was a Grindo sonic MK4 (J.W. Lemmens N.V., Leuven, Belgium) at the Wood Biology and Wood Products group of the Georg-August-University, Göttingen. Each panel was placed horizontally on two sponge rubber pieces placed at the two nodal points of the fundamental resonant frequency. These points were located at a distance from each end, equal to $0.224 \times \mathrm{L}$ ( $\mathrm{L}=$ Length of the sample). The vibration was applied on the top surface of the panel through a light elastic tap in the middle of the panel. The resulting vibration was detected by a transducer which was brought in contact with the radial face of panels, close to the nodal point in order to determine the strongest reading.

The dynamic MOE was calculated based on the equation derived by Hearmon (1966) and Machek et al. (2001). This mathematical expression uses the natural frequency of wood together with data describing the mass and shape of the panel.

$$
\mathrm{MOE}_{\mathrm{dyn}}=\frac{4 \pi^{2} 1^{4} \mathrm{f}^{2} \mathrm{pa}}{\mathrm{m}_{1}^{4} \mathrm{l}}\left(1+\frac{1}{1^{2} \mathrm{~A}} \mathrm{~K}_{1}\right)
$$

Where :

$\mathrm{I}:$ moment of inertia $\left(\mathrm{mm}^{4}\right)$

A : area of the cross section $\left(\mathrm{mm}^{2}\right)$

$\mathrm{f}$ : frequency $(\mathrm{kHz})$

$\mathrm{P}$ : density $\left(\mathrm{kg} \mathrm{m}^{-3}\right)$

$1:$ length (mm)

$\mathrm{K}_{1}=49.48$

$\mathrm{M}_{1}=4.72$

After MOE was determined, panels were split open to assess the severity of wood boring attack visually in order to compare the two methods.

\section{Statistical analysis}

Rates of severity of attack in test panels (Figure 1) and Dynamic MOE values (Figure 2) were square-root transformed before analysis. Residuals were examined to ensure that the transformed data satisfied assumptions of normality and homoscedasticity for ANOVA. Wood boring attack in untreated and treated wood species was compared using a GLM ANOVA model with wood species and treatment as fixed factors. Tukey's post hoc test was performed to detect differences in the severity of attack between untreated and treated wood species (Table 2). A GLM ANOVA model was also used to determine differences in the dynamic MOE values. Tukey's post hoc test was performed to detect differences between untreated and treated wood species that had or had not been exposed to the marine environment (Table 3). 


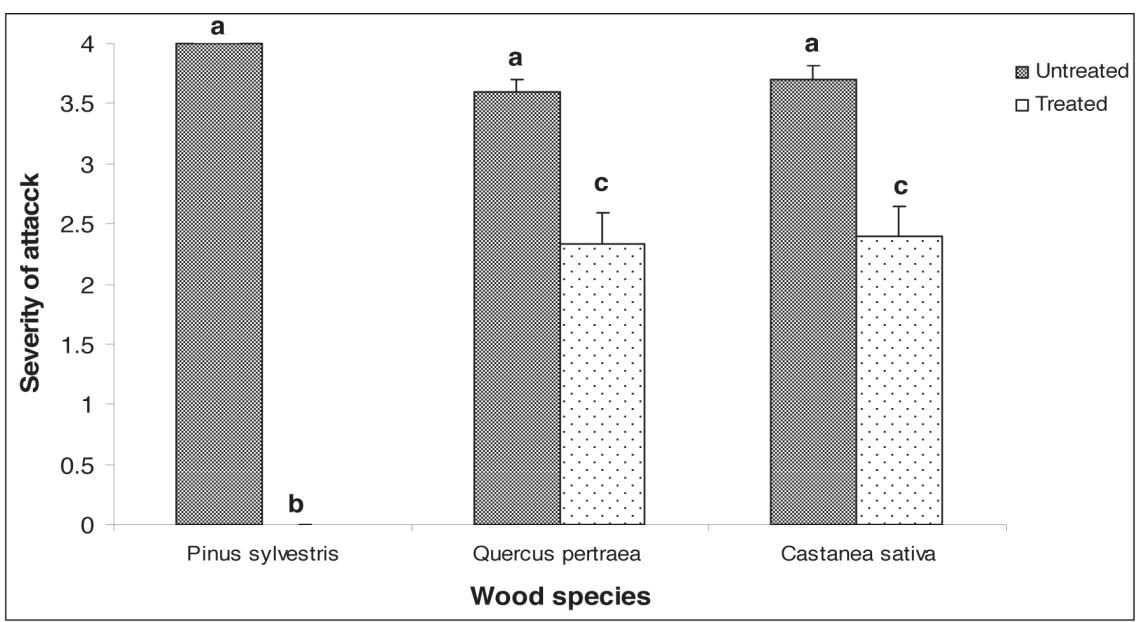

Figure 1. Mean severity of attack by wood boring organisms in test panels of three wood species, untreated and treated with CCA. Wood species with shared letters showed a severity of attack that was not significantly different (GLM ANOVA, Tukey's test, Table 2).

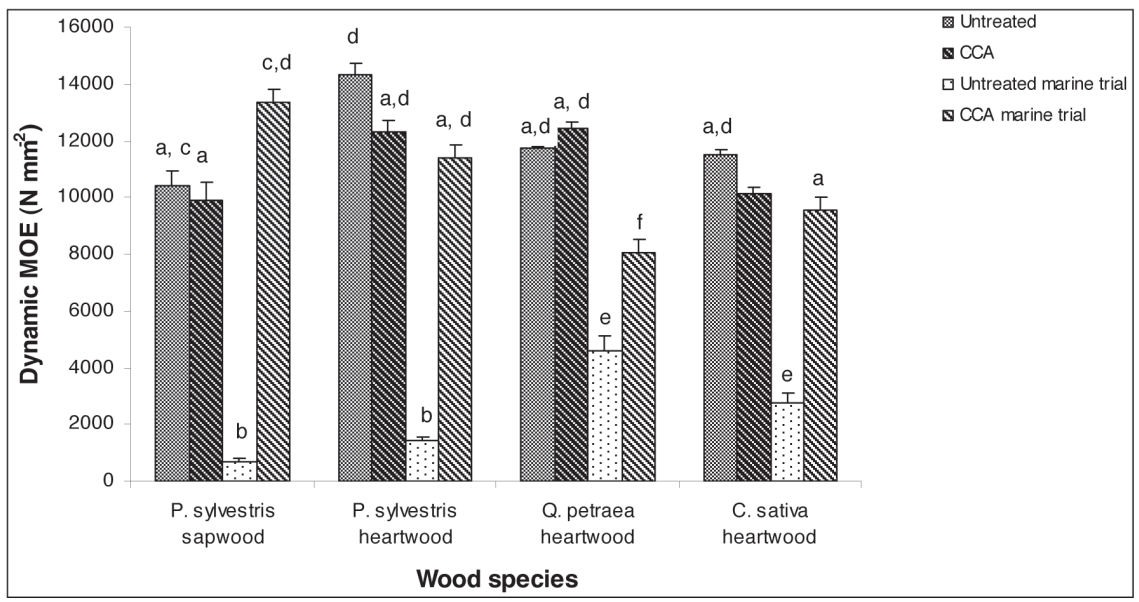

Figure 2. MOE dynamic values (mean $+\mathrm{SE}, \mathrm{n}=3$ ) for untreated and treated test panels of three wood species, P. sylvestris (heartwood and sapwood), Q. petraea (heartwood) and C. sativa (heartwood). Three untreated and treated test panels of each species were exposed to the marine environment for a period of 12 months before the measurements. Different letters indicate significant differences (Tukey's post hoc test of GLM ANOVA, Table 3) between MOE values.

A correlation analysis was performed to investigate how the results obtained by visual assessment varied in relation to MOE. 


\section{RESULTS}

\section{Assessment of CCA retention in test panels}

The retention of CCA, shown both in $\mathrm{kg} \mathrm{m}^{-3}$ and weight percent gain (WPG) varied according to species and wood type (Table 1). The retention in P. sylvestris was much higher in sapwood than heartwood. Of the three wood species Q. petraea heartwood had the lowest CCA retention, almost one-tenth that of. C. sativa. However the retention of $C$. sativa was half of that in $P$. sylvestris heartwood (Table 1).

Table 1. Details of the wood types treated with CCA. Retention is expressed both in volume and as weight percent gain (WPG).

\section{Assessment of severity of attack in test panels using a non-destructive method}

The values of MOE obtained varied significantly with wood species, treatment and exposure to the marine environment (Figure 2, GLM ANOVA, $\mathrm{p}<0.05$, Table 2).

Table 2. Analysis by GLM ANOVA of factors affecting rates of severity of attack with wood species/ treatment as fixed factors. Rates of severity of attack were square-root transformed before analysis

\begin{tabular}{lcccccc}
\hline Source & DF & SeqSS & AdjSS & Adj MS & F & P \\
\hline Wood species/treatment & 5 & 25.9 & 25.9 & 5.2 & 243.7 & 0.000 \\
Error & 34 & 0.7 & 0.7 & 0.0 & & \\
Total & 39 & 26.6 & & & & \\
\hline
\end{tabular}

All panels used in the marine trials showed lower MOE values than for unexposed panels except for exposed Scots pine sapwood treated with CCA (Figure 2, Tukey's post hoc test GLM ANOVA, Table 3). Of all the panels subjected to the marine trial, the untreated panels showed significantly lower MOE values compared to treated panels. Treated panels of Q. petraea heartwood subject to the marine trial showed significantly lower MOE values than all the other treated test panels also exposed to the marine environment. Values of MOE were not significantly different between the treated panels of $P$. sylvestris sapwood and heartwood subject to the marine trial. However, the MOE values obtained in treated panels of $P$. sylvestris sapwood subject to the marine trial were significantly higher than that in panels of C. sativa. In panels not subject to the marine trial, $\mathrm{MOE}$ values did not vary significantly between the untreated and treated panels of the three species (Figure 2, Table 3 ). 
Table 3. Analysis by GLM ANOVA of factors affecting MOE values with wood species, treatment and exposure to the marine environment as fixed factors and MOE values square root transformed

\begin{tabular}{lcccccc}
\hline Source & DF & SeqSS & AdjSS & Adj MS & F & P \\
\hline Wood species & 4 & 49157220 & 49157220 & 12289305 & 5.87 & 0.001 \\
Treatment & 1 & 223433634 & 228876933 & 228876933 & 109.32 & 0.000 \\
Exposure to the marine & & & & & & \\
environment & 1 & 503101155 & 495627629 & 495627629 & 236.72 & 0.000 \\
Error & 41 & 85842973 & 85842973 & 2093731 & & \\
Total & 47 & 861534982 & & & & \\
\hline
\end{tabular}

\section{Severity of attack in test panels from marine trials using a destructive method}

After 12 months, the untreated samples of P. sylvestris including also those used in non-destructive method before braking ( 5 of sapwood and 5 of heartwood) were severely destroyed and easily broken by hand. The average rating for all samples was 4 (complete failure) according to the scale in EN 275 (1992). The untreated samples of Q. petraea and C. sativa were also severely attacked, rating an average 3.5 and 3.6 respectively. The severity of attack in the untreated panels of these two wood species was not significantly different from that in untreated P. sylvestris (Figure 1, Tukey's post hoc test GLM ANOVA, Table 2).

The treatment of panels with CCA significantly decreased the severity of attack by wood borers in all three wood species (Tukey's post hoc test GLM ANOVA, Table 2). Panels of P. sylvestris (both sapwood and heartwood) treated with CCA were significantly less attacked by marine borers than panels of oak or chestnut also treated with CCA. Treated panels of $P$. sylvestris heartwood and sapwood were without marine borer damage (Figure 1). The only marine borer found in any attacked panels was Teredo navalis.

\section{Comparison of MOE values and visual assessment of test panels used in marine trial}

For the untreated wood species subject to the marine trial, there was a very strong negative correlation between the ratings attributed to the severity of wood boring attack by visual assessment and the values obtained by dynamic MOE for the same wood species (Figure 3).

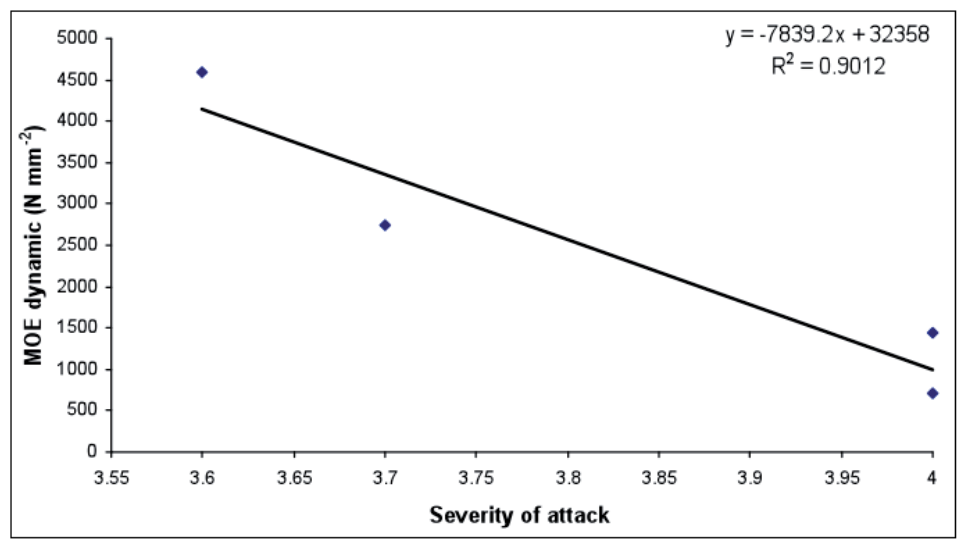

Figure 3. Relationship between severity of attack by wood boring organisms as assessed visually according to EN275 (1992) and dynamic MOE for the untreated wood species shown in figure 2. 
A strong negative correlation (Figure 4) was found between the visual ratings attributed to wood boring attack and the MOE values for CCA treated species shown in figure 2.

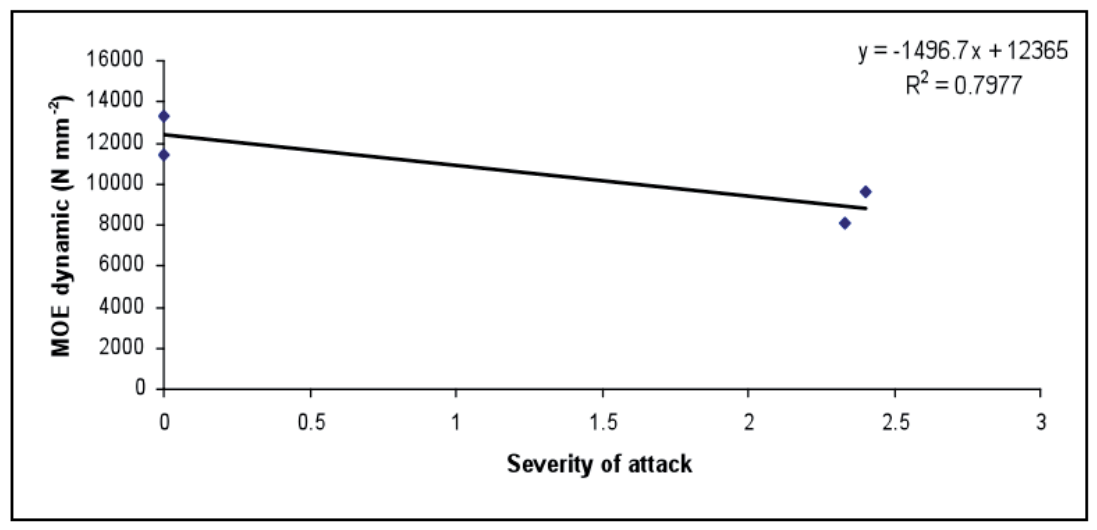

Figure 4. Relationship between severity of attack by wood boring organisms as assessed visually according to EN275 (1992) and dynamic MOE for CCA treated wood species shown in Figure 2.

\section{DISCUSSION AND CONCLUSIONS}

\section{Resistance of the wood to Teredo navalis}

The untreated wood species submitted to the marine trial in Amasra Bay (Table 1) showed little resistance to Teredo navalis, the only wood boring species found in the area. Two other wood boring species Limnoria tripunctata and Chelura terebrans had been previously reported in the area between 1968 and 1969 (DKK 1997) but were absent in the present study. Neither oak (rated 3.6) nor chestnut (rated 3.7) were significantly more resistant to attack by T. navalis than the nondurable timber Scots pine (Figure 1). One of the untreated oak panels was completely destroyed while others were heavily attacked on at least one of their surfaces. Chestnut samples were also heavily attacked and some parts could be broken by hand. In another study a laboratory screening with Limnoria quadripunctata, both chestnut and oak were significantly more resistant to attack by this wood borer than Scots pine (heartwood and sapwood) (Sivrikaya et al. 2009), which was attributed to the presence of extractives with antifeedant properties rather than to the hardness of these wood species. Both chestnut and oak from Turkey have acidic polyphenolic compounds in their heartwood (Balaban and Ucar 2003) that may interfere with the digestion of L. quadripunctata (Sivrikaya et al. 2009). However these compounds did not deter the activity of T. navalis in the present study. Similarly, in a trial conducted in the Oman Sea, all untreated oak samples where completely destroyed after 9 months exposure (Rezanejad 2004). Thus we conclude that the use of untreated Quercus petraea and Castanea sativa is not adequate for maritime construction such as piers and jetties in Amasra Bay.

The samples of chestnut and oak treated with CCA where significantly more resistant to $T$. navalis than the untreated samples of these species (Figure 2). However they were significantly less resistant to teredinid attack than the treated samples of Scots pine (sapwood and heartwood). This is probably related to differences in preservative uptake due to the anatomical properties and 
higher extractive content in chestnut and oak (Taylor et al. 2002, Sivrikaya 2003). Indeed there was a great difference in the retention of CCA between the different wood species. CCA retention in oak was less than $1 \mathrm{~kg} \mathrm{~m}^{-3}$, which is probably related to its refractory properties (Table 2). The CCA retention in chestnut, although higher than in oak $\left(5.8 \mathrm{~kg} \mathrm{~m}^{-3}\right)$ was not enough to protect the panels against $T$. navalis attack. Scots pine has lower density than oak or chestnut, which might explain its higher retention of CCA salts in comparison to oak and chestnut. According to Eaton and Hale (1993) hardwoods treated with multisalt preservatives are less resistant to wood boring attack, particularly in warm waters. Species of Eucalyptus for instance, needed retention levels of CCA of $48 \mathrm{~kg} \mathrm{~m}^{-3}$ to be satisfactorily protected against wood borers in tropical harbours. In the case of Scots pine, even the lower level of retention $\left(11.8 \mathrm{~kg} \mathrm{~m}^{-3}\right)$ in heartwood was enough to provide protection against T. navalis, during the period of exposure. Another study carried out in Queensland Australia showed that even CCA retentions of $2.2 \mathrm{~kg} \mathrm{~m}^{-3}$ were enough to protect sapwood panels of Pinus nigra against wood boring attack for a period 10 months in comparison with the untreated panels of the same species which were attacked by teredinids and pholads (Präel et al. 2000).

Although the samples of Q. petraea and C. sativa treated with CCA showed increased resistance to T. navalis in comparison with the untreated samples, in practical terms treatment with CCA does not confer enough resistance to justify its use as preservative for these timbers when used sawn. CCA may be suitable for natural rounds such as piles or posts when the sapwood can be fully treated. Furthermore, environmental concerns about the use of CCA increase the need to examine alternative methods of wood protection for the marine environment, such as for instance chemically modified wood (Borges 2007, Westin and Rapp 2005).

\section{Assessment of severity of attack in test panels using MOE}

Unexposed untreated and treated panels including three samples of the same wood species showed differences in MOE values but these were not significant. Indeed values of dynamic MOE do not seem to be affected by many waterborne preservative treatments (see for example Winandy et al. 1985, Barnes and Moore 1987), although, waterborne-preservative treatments were shown generally to reduce the mechanical properties of wood (Winandy 1995). In contrast, unexposed panels of oak and chestnut treated with CCA showed significant differences in MOE values when compared to panels of oak and chestnut treated with CCA used in the marine trials. The lower MOE values were due to deterioration by marine borers in both timber species, in addition, some leaching of extractives might have occurred also in treated oak and chestnut after exposure, which might have lowered even more the resistance of these two wood species against degradation by marine borers. In contrast, the MOE values of CCA treated Scots pine sapwood were higher after marine testing than before exposure. The increase in MOE values might be due to the leaching of CCA components underwater.

The strong correlation between the dynamic MOE values in wood attacked by wood boring organisms (both untreated and treated) and the rates of severity of attack attributed by visual assessment shows that dynamic MOE can be used to assess wood boring attack in wooden samples exposed to the marine trial. The advantage of this method in relation to the conventional methods - visual assessment and X - rays - used in the assessment of marine wood boring attack is that it is portable, simple and rapid, does not require calibration, and has high accuracy and reproducibility. The findings regarding non-destructive testing promise new insights for persons working in this field, and for the development of acoustic techniques to determination of service life of wooden material being in-service in marine environment. However, further study is needed to examine resistance of novel wood preservatives, nanobiocides and non-biocidal treatments to marine borers as well as to assess these treatments with of non-destructive techniques using as ultrasonic and acoustic methods. 


\section{REFERENCES}

Balaban, M.; Ucar, G. 2003. Estimation of volatile acids in wood and bark. Holz Als Roh-und Werkstoff 61(6): 465-468.

Barnes, H.M.; Moore, S. 1987. The effects of post-treatment drying schedule on the modulus of elasticity of CCA-treated Southern Pine dimension stock using nondestructive methods. IRG/ WP/3413, 4 pp, Stockholm, Sweden.

Bobat, A. 1995. Marine wood-borer test with preservatives on the coasts of Turkey. IRG $26^{\text {th }}$ Annual Meeting, No: 95-10091, Helsingor, Denmark.

Borges, L.M.S. 2007. Biogeography of wood boring organisms in European Coastal waters and new approaches to controlling borer attack. PhD thesis, Portsmouth, University, Portsmouth, UK, $253 \mathrm{pp}$.

Borges, L.M.S.; Cragg, S.M.; Bergot, J.; Williams, J.R.; Shayler, B.; Sawyer, G. 2008. Laboratory screening of tropical hardwoods for natural resistance to the marine borer Limnoria quadripunctata with an investigation of the role of leachable and non-leachable factors. Holzforschung 62(1): 99-111.

EN 275 1992. Wood preservatives. Determination of the protective effectiveness against marine borers. $16 \mathrm{pp}$.

Cookson, L.J.; Barnacle, J.E. 1987. The performance in Australia after ten years in the sea of single and double preservative treated timber specimens. Material und Organismen 22(2): 139-160.

Cragg, S.M.; Daniel, G. 1992. Chelura terebrans (Crustacea: Amphipoda) is capable of degrading wood independently of its associate, Limnoria. International Research Group on Wood Preservation. IRG/WP/92-4180: 1-9.

Cragg, S.M.; Pitman, A.J.; Henderson, S.M. 1999. Developments in the understanding of the biology of marine wood boring crustaceans and in methods of controlling them. International Biodeterioration and Biodegradation 43(4): 197-205.

DKK. 1997. Türkiye Limanlarında Fouling ve Boring Organizmalar \& Antifouling-Antiboring Boyaların Bu organizmalar Üzerine Etkinliği. Deniz Kuvvetleri Komutanlığı Hidrografi Neşriyatı. DH-1049/DEBSS, 172 p. Çubuklu, İstanbul.

Eaton, R.A. 1989. An international collaborative marine trial to investigate the effect of timber substrate on the efficacy of CCA and CCB wood preservatives. Material und Organismen 24(1): 5179.

Eaton, R.A.; Hale, M.D.C. 1993. Wood decay, pests and protection. Chapman and Hall, London. $554 \mathrm{pp}$.

Fougerousse, M.; Lucas, S. 1976. New experiments on the behaviour of wood preservatives against marine organisms in various test sites. Material und Organismen (suppl 3): 555-568.

Goerlacher, R. 1984. Ein neues Messverfahren zur Bestimmung des Elastizitaetsmodulus von Holz. Holz als Roh-u. Werkstoff 42 (6): 219-222. 
Hearmon, R.F.S. 1966. Vibration testing of wood. Forest Products Journal 16(8): 29-39.

Machek, L.; Militz, H.; Sierra-Alvarez, R. 1998. A dynamic approach to assess the modulus of elasticity in wood decay testing. IRG/WP/98-20139, 29th Annual meeting of the Int. Research Group on Wood Preservation, Maastricht, The Netherlands, 9 pp.

Machek, L.; Militz, H.; Sierra-Alvarez, R. 2001. The use of an acoustic technique to assess wood decay in laboratory soil-bed tests. Wood Science and Technology 34(6): 467-472.

Machek, L. ; Edlund, M.L. ; Sierra-Alvarez, R. ; Militz, M. 2004. A non-destructive approach for assessing decay in preservative treated wood. Wood Science and Technology 37(5) : 411-417.

Menzies, R. J. 1957. The marine borer family Limnoriidae (Crustacea, Isopoda). Part I: northern and central America: systematics distribution, and ecology. Bulletin of Marine Science of the Gulf and Caribbean 7(2): 101-200.

Morin, C.R.; Christie, S.; Fehr, K. 2007. Ultrasonic Inspection of Waterfront Timber Structures: An Economic Advantage to the Marine Facility Owner. Civil Engineering Practice 22(2): 5-18.

Nicholas, D. 1973. Wood deterioration and its prevention by preservative treatments: Degradation and Protection of Wood. In: Coté A (ed) Syracuse Wood Science Series. Syracuse University Pres, $380 \mathrm{pp}$.

OGM. 2007. Turkiye'de Orman Ekosistemlerinin İzlenmesi L I ve L II Programlari. T.C. Cevre ve Orman Bakanlığı, Orman Genel Mudurluğu, Ankara. 40p.

Präel, A.; Cragg, S.M.; Eaton, R.A. 2000. Preliminary field and laboratory findings regarding the efficacy of a novel anti-marine wood borer agent. $31^{\text {st }}$ Annual Meeting of The International Research Group on Wood Preservation, Kona Surf, USA, IRG/WP 00-10380, 11 pp.

Rao, M.V.; Kuppusamy, V.; Rao, K.S.; Santhakumaran, L.N. 2001. Leaching of CCA preservative from treated timber in marine environment. IRG/WP 01-30254, 32 $2^{\text {nd }}$ Annual Meeting, Nara, Japan, 18 pp.

Rezanejad, A. 2004. Resistance of Teak, Balau, Keruing and Chengal wood species against marine borers attack. $35^{\text {th }}$ Annual meeting of the Int. Research Group on Wood Preservation, Ljubljana, Slovenia, IRG/WP 04-10513, 9 pp.

Sivrikaya, H. 2003. The impregnability and Durability Characteristics of Sapwood and Heartwood. PhD thesis, Karaelmas University of Zonguldak, Graduate School of Natural and Applied Sciences, Zonguldak, Turkey. 179 pp.

Sivrikaya, H.; Cragg, S.M.; Borges, L.M.S. 2009. Variation in resistance to marine borers in commercial timbers from Turkey, as assessed by marine trial and laboratory screening. Turkish Journal of Agriculture and Forestry 33: 569-576.

Taylor, A.M.; Gartner, B.L.; Morrell, J.J. 2002. Heartwood Formation and Natural Durability- A Review. Wood and Fiber Science 34(4): 587-611.

Turner, R.D. 1966. A survey and illustrated catalogue of the Teredinidae. The Museum of Comparative Zoology, Harvard University, Cambridge, M.A. USA, 265 pp. 
Turner, R.D. 1971. Methods d'identification des perforants et des champignons en millieu marin. In: Jones, E. B. G. \& Eltringham, S. K. (eds.) Les Perforants, les Champignons et les Salissures du Bois en Millieu Marin. OECD, Paris, pp. 69-73.

U.S-EPA. 2008. Chromated Copper Arsenate (CCA). Reregistration Eligbility Decision (RED) for Chromated Arsenicals (Case 0132), [on line] <http://www.epa.gov/oppad001/reregistration/ cca/> [consulted September 25, 2008].

Westin, M.; Rapp, A.O. 2005. Resistance of Modified Wood to Marine Borers: Results from a Five Year Field Test According to EN 7. The second European Conference on Wood Modification, Göttingen, Germany.

Williams, J.R.; Cragg, S.M.; Borges, L.M.S.; Shayler, B. 2004. Evaluating the natural durability of a number of lesser known species of Ghanaian hardwoods using a short-term laboratory assay. IRG/WP 04-10540. The International Research Group on Wood Preservation, Stockholm.

Winandy, J.E.; Bone, R.S.; Bendtsen, B.A. 1985. The interaction of CCA preservative treatment and redrying: effects on the mechanical properties of Southern Pine. Forest Products Journal 35(10): $62-68$.

Winandy, J.E. 1995. Effects of waterborne preservative treament on mechanical properties: A review. Proceedings Ninety-First Annual Meeting of The American Wood-Preservers' Association. Vol.91, New York.

Woods, T.L.; Laks, P.E.; Blewett, T.C.; Fears, R. 1995. A combination of chlorothalonil and chlorpyrifos for more effective wood preservation. IRG $26^{\text {th }}$ Annual Meeting, No: 95-30067, Helsingor, Denmark. 